\title{
Influence of temperature on the growth of Pseudomonas putida
}

\author{
Md. Sakil Munna ${ }^{1}$, Zebunnesa Zeba ${ }^{2}$ and Rashed Noor ${ }^{1 *}$ \\ ${ }^{1}$ Department of Microbiology, Stamford University Bangladesh, 51 Siddeswari Road, Dhaka 1217, \\ Bangladesh; ${ }^{2}$ Department of Natural Science, Stamford University Bangladesh, 51 Siddeswari Road, Dhaka \\ 1217, Bangladesh
}

Received 13 February 2015/Accepted 12 April 2015

\begin{abstract}
Lots of reports on the generation of stress by increase in temperature in the bacterial cells especially in Escherichia coli has been observed so far. Current study further emphasized such effect on the cells of Pseudomonas putida (SUBP03). Conventional methods relating growth assessment of bacteria were employed. The optical density of bacterial cells at $600 \mathrm{~nm}\left(\mathrm{OD}_{600}\right)$ in the minimal broth along with the culturable cells were assessed in the form of colony forming units (CFUs) in the minimal agar media at different temperatures $\left(27^{\circ} \mathrm{C}, 30{ }^{\circ} \mathrm{C}, 33{ }^{\circ} \mathrm{C}, 37^{\circ} \mathrm{C}\right.$ and $\left.40{ }^{\circ} \mathrm{C}\right)$. Morphological observations were made to further clarify the bacterial physiology and the spot tests were performed to examine the cell viability. Cells of $P$. putida (SUBP03) were found to grow vigorously at $30{ }^{\circ} \mathrm{C}$, while the growth was found to decline at lower temperature $\left(27^{\circ} \mathrm{C}\right)$ and along with the increase in temperature (at $33{ }^{\circ} \mathrm{C}, 37$ ${ }^{\circ} \mathrm{C}$ and $40{ }^{\circ} \mathrm{C}$ ). However, the morphological changes were insignificant. Furthermore, cells were noticed to completely lose culturability at $40{ }^{\circ} \mathrm{C}$ after 48 hours.
\end{abstract}

Key words: Critical growth temperature; High temperature stress; Optimum growth temperature; Pseudomonas putida; Viable but non culturable (VBNC) cells

Pseudomonas species are well-known rod-shaped, flagellated, gram-negative bacterium $(1,2)$. However, Pseudomonas often persisting in the environment like Escherichia coli, which may face many growth retarding stress factors such as nutrient depletion, temperature fluctuation, variation in $\mathrm{pH}$ and redox potential, limited water activity (aw), elevated level of reactive oxygen species (ROS), osmotic imbalance together with anomalous solute concentrations, etc. (323). Notably, bacteria were found to utilize unified strategies to deal with the environmental stress (3-5, 24-26). Nevertheless, several studies apparently suggested the expression of the global molecular chaperones, which maintain the cellular homeostasis, including rpoE, rpoS and rpoH genes in E. coli; dnaK, dnaJ, and grpE in Pseudomonas spp.; CspB and CspE in Bacillus spp. Cells; and GroEL and DnaK proteins in Salmonella spp. (3-5, 7, 8, 10, 12, 13, 19, 21-23, 2740).

In acquiring stress, our earlier studies revealed four independent aspects, wherein (i) the influence of the temperature up-shift on the generation of oxidative stress (19, 22, 37); (ii) impulsive accretion of the reactive oxygen species (ROS) at the early stationary phase of bacterial growth (12), (iii) the origination of oxidative stress upon supplementation of the oxidative agent, $\mathrm{H}_{2} \mathrm{O}_{2}(21,23)$ and (iv) the hindering effect of

${ }^{*}$ Corresponding Author: Mailing address. Dr. Rashed Noor, Department of Microbiology, Stamford University Bangladesh, 51 Siddeswari Road, Dhaka 1217, Bangladesh, Bangladesh; E-mail: noor.rashed@yahoo.com. different aeration speed on the formation of colony forming units due to the suggestive endogenous oxidative stress (22).

In all instances, the physiological influence of the external and internal oxidative stress $(12,18,22,23)$ and heat stress (unpublished) in $E$. coli (SUBE01), Pseudomonas aeruginosa (SUBP01), Pseudomonas fluorescens (SUBP02), Bacillus spp. (SUBB01) and Salmonella spp. (SUBS01) has been inquired well and evidently brought the new information on the defense strategy against stress and the ascertainment of their critical growth temperature (unpublished) as observed through their sustainability in growth pattern. These previous findings led us to extend the research interest in other bacterial cells primarily to assess the optimum and critical growth temperature of our laboratory stock culture of Pseudomonas putida (SUBP03).

\section{MATERIALS AND METHODS}

Conventional experiments measuring the bacterial growth were conducted as described earlier by Nur et al. (23). Laboratory stock cultures of Pseudomonas putida (SUBP03) was used in this study. Minimal media (dextrose $1.0 \mathrm{~g} / \mathrm{L}$, dipotassium phosphate $7.0 \mathrm{~g} / \mathrm{L}$, monopotassium phosphate $2.0 \mathrm{~g} / \mathrm{L}$, sodium citrate $0.5 \mathrm{~g} / \mathrm{L}$, magnesium sulfate $0.1 \mathrm{~g} / \mathrm{L}$ and ammonium sulfate $1.0 \mathrm{~g} / \mathrm{L}$ ) for both agar (MA) and broth (MB) were used for the assay of the bacterial culturability (19). After 24 hour incubation on minimal agar plates at $37{ }^{\circ} \mathrm{C}$, one loopful of each of the bacterial culture was introduced into $5 \mathrm{ml}$ minimal broth followed by $100 \mathrm{rpm}$ (rotation per minute) at $37{ }^{\circ} \mathrm{C}$ for $4-6$ hours (pre-culture). After adjusting optical density of the pre-culture at $600 \mathrm{~nm}\left(\mathrm{OD}_{600}\right)$ to $0.1,30 \mu \mathrm{L}$ each was introduced into 2 different sets of $30 \mathrm{ml}$ of minimal broth and incubated at $27{ }^{\circ} \mathrm{C}, 30{ }^{\circ} \mathrm{C}, 33{ }^{\circ} \mathrm{C}, 37$ ${ }^{\circ} \mathrm{C}$ and $40{ }^{\circ} \mathrm{C}$ at shaking condition (100 rpm). At every 12 hours cell growth was monitored by measuring $\mathrm{OD}_{600}$, and the formation of colony forming units (CFUs) were estimated by counting the colonies up to 72 hours at every 24 hour intervals 
a

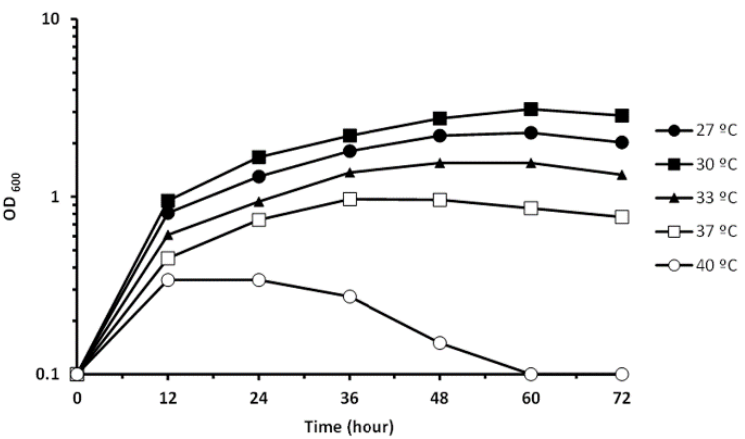

b

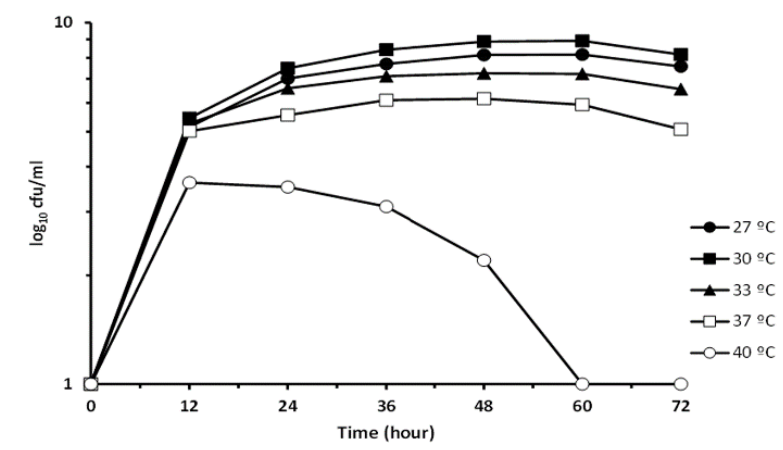

FIG. 1. Assessment of growth of Pseudomonas putida (SUBP03) at $27{ }^{\circ} \mathrm{C}, 30^{\circ} \mathrm{C}, 33{ }^{\circ} \mathrm{C}, 37^{\circ} \mathrm{C}$ and $40{ }^{\circ} \mathrm{C}$ in terms of $\mathrm{OD}_{600}($ a) and $\mathrm{CFU}$ (b) in shaking condition up to 72 hours. Notably, when the P. putida (SUBP03) cells were grown at $27{ }^{\circ} \mathrm{C}, 33{ }^{\circ} \mathrm{C}$ and $37^{\circ} \mathrm{C}$, substantial reduction in cell turbidity (a) as well as in the generation of the colony forming units (CFUs) were observed (b) up to 72 hours of incubation periods in minimal media. Interestingly, a dramatically reduction in both cell turbidity and colony forming units (CFUs) were observed when the cells were challenged at $40{ }^{\circ} \mathrm{C}$ after 12 hours to 72 hours of incubation periods.

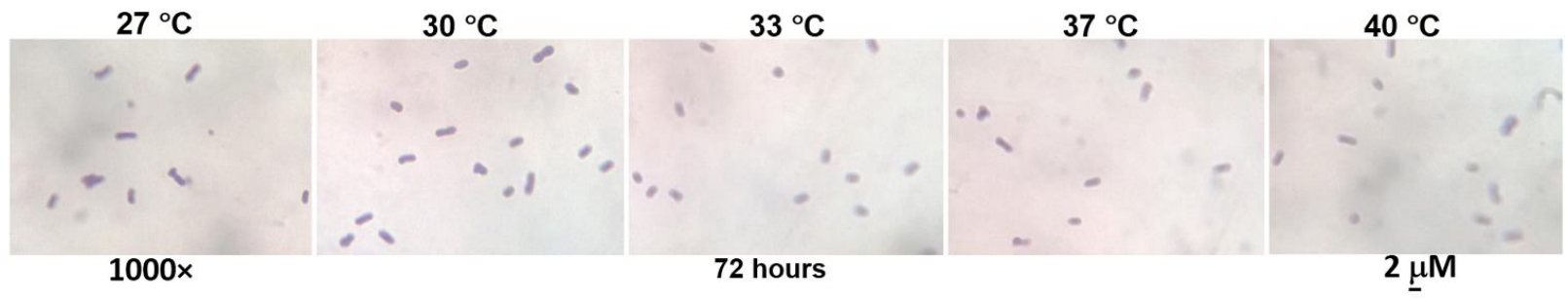

FIG. 2. Morphological changes of Pseudomonas putida (SUBP03) cells at $27{ }^{\circ} \mathrm{C}, 30^{\circ} \mathrm{C}, 33^{\circ} \mathrm{C}, 37^{\circ} \mathrm{C}$ and $40{ }^{\circ} \mathrm{C}$ after 72 hours of incubation periods. Surprisingly, no morphological change was observed under light microscope.

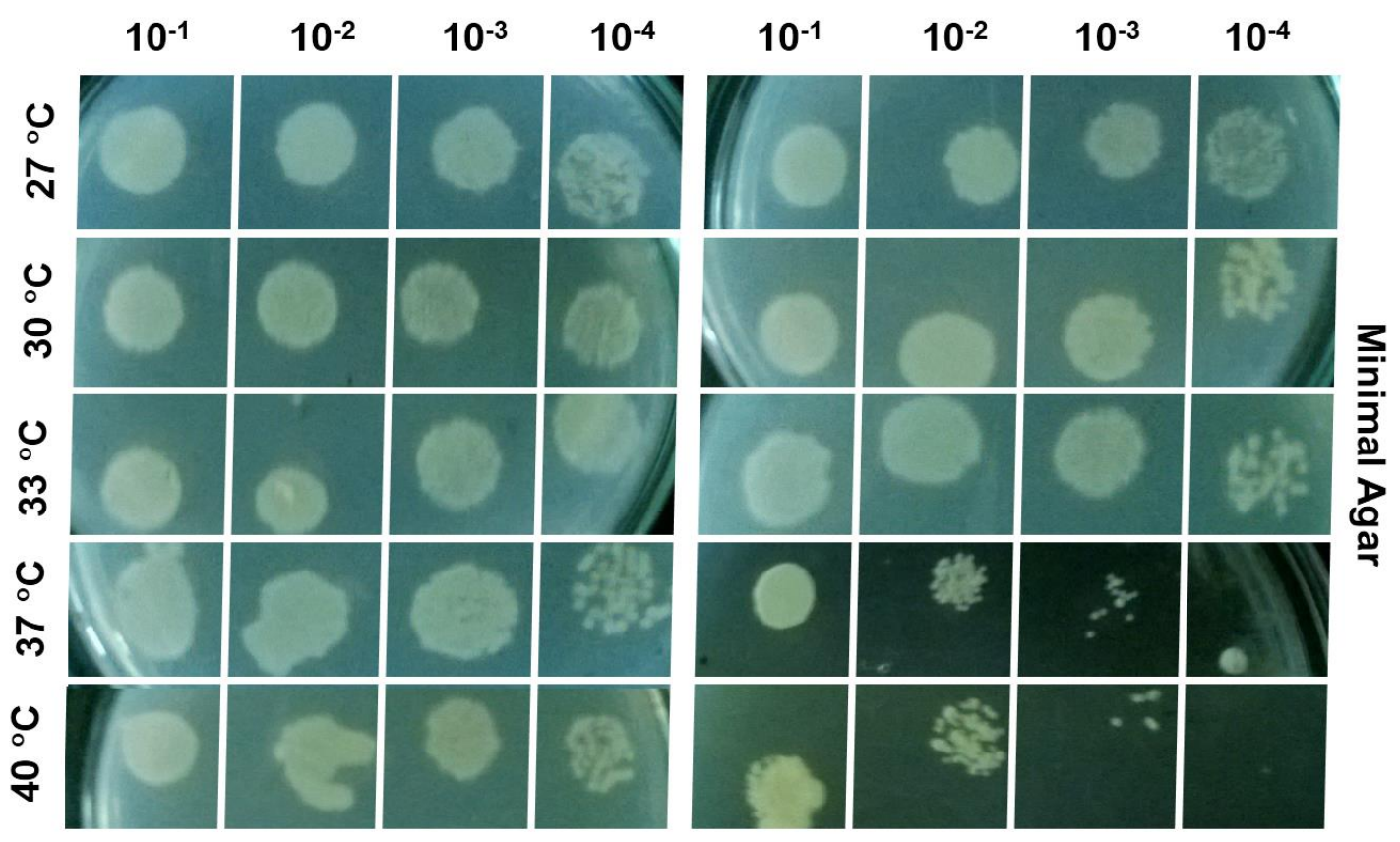

12 Hours

72 Hours

FIG. 3. Confirmative demonstration of culturability and survival potential of Pseudomonas putida (SUBP03) through spot tests in minimal agar media at $27{ }^{\circ} \mathrm{C}, 30^{\circ} \mathrm{C}, 33{ }^{\circ} \mathrm{C}, 37^{\circ} \mathrm{C}$ and $40^{\circ} \mathrm{C}$ temperature after 12 hours and 72 hours of incubation periods. Notably, a relatively slower growth was observed when bacterial cells were grown at $37{ }^{\circ} \mathrm{C}$ and $40{ }^{\circ} \mathrm{C}$ on minimal agar after 72 hours of incubation periods. 
(19, 21-23).

For the observation of cell morphology and arrangements, simple staining (Crystal Violet, Hucker's Solution) was applied as previously done (21-23). An aliquot of $10 \mu \mathrm{L}$ from each bacterial culture suspension was removed by 12 hours intervals and the shape and organization of cells were observed under light microscope (Optima Biological Microscope G206, manufactured in Taiwan) at $1000 \times$ magnification (21). Finally spot tests were conducted to further confirm the bacterial viability under temperature stress. As described previously, each of the bacterial culture suspensions was serially diluted in $9 \mathrm{~m}$ nutrient broth to obtain up to $10^{-4}$ fold dilution $(19,21-23)$. From each dilution, an aliquot of $5 \mu \mathrm{l}$ was dropped on to the minimal agar, dried off for 15 minutes, and finally the plates were incubated at $37{ }^{\circ} \mathrm{C}$ for 24 hours. Spotting on the agar was accomplished at every 12 hours of growth $(19,21-23)$.

\section{RESULTS AND DISCUSSION}

Pseudomonas putida (SUBP03) grows best at 30 ${ }^{\circ} \mathbf{C}$. The optimum growth temperature for Pseudomonas putida (SUBP03) was assessed through the measurement of optical density of bacterial cells at 600 $\mathrm{nm}\left(\mathrm{OD}_{600}\right)$ in the minimal broth along with the detection of culturable cells in the form of colony forming units (CFUs) in the minimal agar media up to 72 hours. After 12 hours of incubation at $30{ }^{\circ} \mathrm{C}$ the cell number was found to be increase rapidly by approximately $4 \operatorname{logs}$ (Figure 1), which was comparable to those cells grown at $27{ }^{\circ} \mathrm{C}, 33{ }^{\circ} \mathrm{C}, 37^{\circ} \mathrm{C}$ and $40^{\circ} \mathrm{C}$. Surprisingly, under the light microscope, no morphological change was observed (Figure 2). Besides, a steady growth was noticed through spot at 27 ${ }^{\circ} \mathrm{C}, 30{ }^{\circ} \mathrm{C}$ and $33{ }^{\circ} \mathrm{C}$ (Figure 3). Hence, the optimum temperature of our test bacterial strain of Pseudomonas putida (SUBP03) was recorded to be $30{ }^{\circ} \mathrm{C}$. Present finding is quite consistent with the earlier studies where $P$. putida has been noticed to exhibit highest growth at $30{ }^{\circ} \mathrm{C}$ too $(3-5)$.

Critical growth temperature of $P$. putida (SUBP03) was recorded to be $40{ }^{\circ} \mathrm{C}$. The inability to grow at 37 ${ }^{\circ} \mathrm{C}$ led our interest further to examine the critical growth temperature for the test bacterial strain of Pseudomonas putida (SUBP03). While a gradual decrease was observed in both CFU and the cell turbidity (Figure 1), when the cells were grown at 40 ${ }^{\circ} \mathrm{C}$ after 12 to 72 hours of incubation periods, respectively, a relatively shower growth was noticed through spot, when bacterial cells were grown at $40{ }^{\circ} \mathrm{C}$ (Figure 3), whereas a complete growth cessation was observed at $41{ }^{\circ} \mathrm{C}$ (data not shown). Previously, the maximum growth temperatures of Pseudomonas putida were recorded to be $35{ }^{\circ} \mathrm{C}$ by Balows et al. (3). In the current study, Pseudomonas putida (SUBP03) were found to lose the culturability completely at $41{ }^{\circ} \mathrm{C}$. Hence the critical growth temperature of this Pseudomonas putida was recorded to be $40{ }^{\circ} \mathrm{C}$, which is indeed corroborating with the data achieved as stated in the earlier investigation (4).

\section{CONCLUSION}

In a separate study, the oxidative stress events were investigated within $P$. aeruginosa (SUBP01) and $P$. fluorescens (SUBP02) against the oxidant $3 \mathrm{mM} \mathrm{H} \mathrm{H}_{2}$ in a concentration (unpublished). The findings of the current study revealed the heat shock state in case of $P$. putida (SUBP03), which may further increment the existing knowledge on the stress response in Pseuomonas spp. However, the limitation of this study underlies the lack of study in genetic level with the presentation of preliminary data. However, detection of the optimal and critical growth temperatures of $P$. putida (SUBP03) may draw interest within the closely related fields. Nevertheless, the expressional analyses of certain heat shock genes are worth to understand the detailed scenario as well as to complete the current investigation.

\section{ACKNOWLEDGMENTS}

Authors are thankful to Mushfia Malek for her technical assistance during the experiments.

\section{REFERENCES}

1. Harwood CS, Fosnaugh K, Dispensa M. 1989. Flagellation of Pseudomonas putida and analysis of its motile behavior. J. Bacteriol. 171: 4063-4066.

2. Boopathi E, Rao KS. 1999. A sideophore from Pseudomonas putida type A1: structural and biological characterization. Biochim. Biophys. Acta. 1435: 3040 .

3. Balows A, Troper HG, Dworkin M, Harder W, Schleifer K. 1992. The prokaryotes, $2^{\text {nd }}$ ed. Springer Science and Business Media, New York.

4. Manzanera M, Aranda-Olmedo I, Ramos JL, Marques S. 2001. Molecular characterization of Pseudomonas putida KT2440 rpoH gene regulation. Microbiol. 147: 1323-1330.

5. Fonseca P, Moreno R, Rojo F. 2011. Growth of Pseudomonas putida at low temperature: global transcriptomic and proteomic analyses. Env. Microbiol. Reports. DOI:10.1111/j.1758-2229.2010.00229.x

6. Givskov M, Eberl L, Moller S, Poulsen LK, Molin S. 1994. Responses to nutrient starvation in Pseudomonas Putida KT2442: analysis of general crossprotection, cell shape, and macromolecular content. J Bacteriol. 176: 7-14.

7. Jorgensen F, Bally M, Chapon-Herve V, Michel G, Lazdunski A, Williams P, et al. 1999. RpoS-dependent stress tolerance in Pseudomonas aeruginosa. Microbiology. 145: 835-844.

8. Miller CD, Mortensen WS, Braga GUL, Anderson AJ. 2001. The rpoS gene in Pseudomonas syringae is important in surviving exposure to the nearUV in sunlight. Curr Microbiol. 43: 374-377.

9. Kabir, MS, Yamashita, D, Noor R, Yamada M. 2004. Effect of sigma-S on sigma-E -directed cell lysis in Escherichia coli early stationary phase. J. Mol. Microbiol. Biotechnol. 8: 189-194.

10. Heeb S, Valverde C, Gigot-Bonnefoy C, Haas D. 2005. Role of the stress sigma factor RpoS in GacA/RsmA-controlled secondary metabolism and resistance to oxidative stress in Pseudomonas fluorescens CHA0. FEMS Microbiol. Lett. 243: 251-258

11. Nystrom, T. 2005. Role of oxidative carbonylation in protein quality control and senescence. EMBO. J. 24: 1311-1317.

12. Noor R, Murata M, Nagamitsu H, Klein G, Raina S, Yamada M. 2009. Dissection of $\sigma \mathrm{E}$ dependent cell lysis in Escherichia coli: roles of $\mathrm{RpoE}$ regulators RseA, RseB and periplasmic folding catalyst Ppid. Genes Cells. 14: 885-899.

13. Noor R, Murata M, Yamada M. 2009. Oxidative stress as a trigger for growth phase-specific $\sigma^{\mathrm{E}}$ dependent cell lysis in Escherichia coli, J. Mol. Microbiol. Biotechnol. 17: 177-187.

14. Ju KS, Parales RE. 2010. Nitroaromatic compounds, from synthesis to biodegradation. Microbiol. Mol. Biol. R. 74: 250-272.

15. Fuchs G, Boll M, Heider J. 2011. Microbial degradation of aromatic compounds - from one strategy to four. Nat. Rev. Microbiol. 9: 803-816.

16. Kivisaar M. 2011. Evolution of catabolic pathways and their regulatory systems in synthetic nitroaromatic compounds degrading bacteria. Mol. Microbiol. 82: 265-268.

17. Deepika G, Karunakaran E, Hurley CR, Biggs CA, Charalampopoulos D. 2012. Influence of fermentation conditions on the surface properties and adhesion of Lactobacillus rhamnosus GG. Microb Cell Fact. 11: 116.

18. Murata M, Noor R, Nagamitsu H, Tanaka S, Yamada M. 2012. Novel pathway directed by $\sigma \mathrm{E}$ to cause cell lysis in Escherichia coli. Genes Cells. 17: 234-247. 
19. Noor R, Islam Z, Munshi SH, Rahman F, 2013. Influence of temperature on Escherichia coli growth in different culture media. J. Pure. Appl. Microb. 7: 899-904.

20. Shimizu K. 2013. Regulation systems of bacteria such as Escherichia coli in response to nutrient limitation and environmental stresses. Metabolites. 4: $1-35$.

21. Munna MS, Nur IT, Rahman T, Noor R. 2013. Influence of exogenous oxidative stress on Escherichia coli cell growth, viability and morphology. Am. J. BioScience. 1: 59-62.

22. Munna MS, Tamanna S, Afrin MR, Sharif GA, Mazumder C, Kana KS, et al. 2014. Influence of Aeration Speed on Bacterial Colony Forming Unit (CFU) Formation Capacity. Am. J. Microbiol. Res. 2: 47-51.

23. Nur IT, Munna MS, Noor R. 2014. Study of exogenous oxidative stress response in Escherichia coli, Pseudomonas spp., Bacillus spp. and Salmonella spp. Turk. J. Biol. 38: 502-509.

24. Price CW. 2002. General stress response. In: Bacillus Subtilis and its closest relatives: From genes to cells. American Society for Microbiology, Washington, DC, p. 369-384.

25. Phillips ZE, Strauch MA. 2002. Bacillus subtilis sporulation and stationary phase gene expression. Cell Mol. Life Sci. 59: 392-402.

26. Huillet E, Tempelars M, Andre- Leroux G, Wanapaisan P, Bridoux L, Makhzamis M, et al. 2012. PIcRa. a new qurum-sensing regulator from Bacillus cereus, play a role in oxidative stress response and cystein metabolism in stationary phase. Genetique. Microbienneet. Environment. 7: 51047.

27. Ananthan J, Goldberg AL, Voellmy R. 1986. Abnormal proteins serve as eukaryotic stress signals and trigger the activation of heat shock genes. Science 232: 522-524.

28. Sarniguet A, Kraus J, Henkels MD, Muehlchen AM, Loper JE. 1995 The sigma factor $(\sigma \mathrm{S})$ affects antibiotic production and biological control activity of Pseudomonas fluorescens Pf-5. Proc Natl Acad Sci USA. 92 12255-12259.

29. Mayr B, Kaplan T, Lechner S, Scherer S. 1996. Identification and purification of a family of dimeric major cold shock protein homologs from the psychrotrophic Bacillus cereus WSBC 10201. J. Bacteriol. 178: $2916-2925$
30. Ramos-Gonzalez MI, Molin S. 1998. Cloning, sequencing, and phenotypic characterization of the rpoS gene from Pseudomonas putida KT2440, J. Bacteriol. 180: 3421-3431

31. Suh SJ, Silo-Suh L, Woods DE, Hassett DJ, West SHE, Ohman DE. 1999 Effect of rpoS mutation on the stress response and expression of virulence factors in Pseudomonas aeruginosa. J Bacteriol. 181: 3890-3897.

32. Whistler CA, Stockwell VO, Loper JE. 2000. Lon protease influences antibiotic production and UV tolerance of Pseudomonas fluorescens Pf-5. Appl. Environ. Microbiol. 66: 2718-2725.

33. Nitta T, Nagamitsu H, Murata M, Izu H, Yamada M. 2000. Function of the $\sigma \mathrm{E}$ regulon in dead-cell lysis in stationary phase Escherichia coli. J Bacteriol 182: 5231-5237.

34. Miller CD, Kim YC, Anderson AJ. 2001. Competitiveness in root colonization by Pseudomonas putida requires the rpoS gene. Can. J. Microbiol. 47: 41-48.

35. Periago PM, Schaik WV, Abee T, Wouters JA. 2002. Identification of proteins involved in the heat stress response of Bacillus cereus ATCC 14579. Appl. Environ. Microbiol. 68: 3486-3495.

36. Stockwell VO, Loper JE. 2005. The sigma factor RpoS is required for stress tolerance and environmental fitness of Pseudomonas fluorescens Pf-5, Microbiol. 151: 3001-3009.

37. Yamada M, Noor R, Nagamitsu H, Murta M. 2009. The higher temperature, the more oxidative stress and lysis in Escherichia coli. The 3rd International Conference on Fermentation Technology for Value Added Agricultural Products, KhonKaen, Thailand.

38. Akerfelt M, Morimoto RI, Sistonen L. 2010. Heat shock factors: Integrators of cell stress, development, and lifespan. Nat. Rev. Mol. Cell. Biol. 11: 545555 .

39. Morimoto RI. 2012. The Heat Shock Response: Systems biology of proteotoxic stress in aging and disease. Cold Spring Harb. Symp. Quant. Biol. 76: 91-99.

40. Heeb S, Valverde C, Gigot-Bonnefoy C, Haas D. 2005. Role of the stress sigma factor RpoS in GacA/RsmA-controlled secondary metabolism and resistance to oxidative stress in Pseudomonas fluorescens CHA0. FEMS Microbiol. Lett. 243: 251-258. 